\title{
1995年兵庫県南部地震による神戸市西部長田地域の 地震災害と地質・地盤
}

\section{Earthquake Damage caused by the 1995 Hyogoken-Nanbu Earthquake and Geological Background in Nagata District, Western Part of Kobe City, Japan}

Key words : 兵庫県南部地震 Hyogoken-Nanbu Earthquake，木造倒壊家屋 collapsed wooden buildings， 軟弱地盤 soft ground，神戸市長田地区 Nagata district in Kobe city

\begin{abstract}
Nagata district can be divided into two areas on the basis of geological conditions, particularly, Jyomon coast line which was formed by Jyomon transgression about 6000 years ago.

The first area is the northern part which is characterized by the uplift of Suma Fault which forms mountains and hilly lands. The mountains are composed of Cretaceous granitic rocks. This area has very weak earthquake disasters except for slope failure,even though active fault(Suma Fault) is located on this area. The hilly lands consist of Plio-Pleistocene Osaka Group. This earthquake had caused various damages on this hilly lands. Many wooden buildings which were located on the bankings were collapsed by the 1995 Hyogoken-Nanbu Earthquake. Serious damaged grounds were observed on the margin of the hilly lands.

The second area is alluvial formation which is located in southern part of the Jyomon coast line. This area is composed of clay rich deposits. Concentrative damaged area caused by the 1995 Hyogoken-Nanbu Earthquake is located in this area. About $70 \%$ of Wooden buildings were collapsed and elevated-railroads were destroyed by the 1995 Hyogoken-Nanbu Earthquake. The reason for this seriously damaged wooden buildings is soft ground which is mainly composed of clay. Geologic hazards associated with this great earthquake are slightly weak in sand rich alluvial formation area compared with those of the clay rich alluvial formation area.

The 1995 Hyogoken-Nanbu Earthquake had caused various damages. The damage associated with the earthquake had close relation to the geologic conditions and the ground.
\end{abstract}

\section{1. は じめに}

神戸市市街地西部，長田区付近は今回の地震で木造家

* 神戸大学発達科学部 Faculty of Human Development, Kobe University
屋の多くが倒壊するなど最も大きな被害を受けた地域 で，その被害は約6,000年前の縄文海岸線以南の粘土層 優勢地域に集中している1)。一方, 最南部の砂州地域や 北部の主に砂からなる沖積層地域では木造家屋の倒壊が 少なくなり，被害が小さくなる。北部の大阪層群よりな る丘陵地域では一般に被害は小さいが, 丘陵地縁辺部の 
人工改変地形地域では大きな被害を受けている。また， 須磨断層近傍であっても花崗岩や神戸層群が分布する良 好な地盤地域では大きな被害は見られない。このよう に, 長田付近の地震による被害は地質の違いを顕著に反 映しており, 地質の違いが被害の程度を決める大きな要 素であると考えられる。しかし，これまで詳しい野外調 査に基づく地質と地震被害との関係は十分に検討された とは言えない。そこで, 本論では地質の違いが家屋や地 盤被害とどのような関係にあるのか, 個々の地質区分毎 に詳細に検討したのでここに報告する。

\section{2. 神戸市長田付近の地質のあらまし}

調査地域である神戸市長田付近は神戸の中心部三宮か ら西へ約数 $\mathrm{km}$ の市街地西部で, 淡路島の北東対岸に当 る(図-1)。長田付近の微地形区分は栗田ほか2 2 による と山地, 丘陵地, 扇状地, 緩扇状地, 低地に区分される
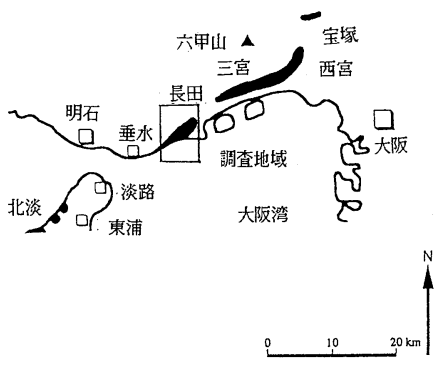

図 - 1 調査地域の位置図

調査地域を四角で囲んで示した，黒つぶしは家屋 倒壊集中地域。
(図-2)。山地は標高約 $90 \sim 320 \mathrm{~m}$ で, 六甲山系の西 南部に当る ${ }^{3)}$ 。丘陵地は標高約 $40 \sim 90 \mathrm{~m}$ で, 山麓に 点在して分布する。丘陵地の南部には苅藻川の土砂供給 によって形成された緩扇状地が分布する。丘陵地と緩扇 状地の境界付近に縄文海岸線の存在が予想される。海岸 部の低地には苅藻川からの土砂供給と速い潮流により形 成された砂州が分布する4)。

神戸市長田付近は新第三紀以降の被覆層である新期堆 積層とそれ以前の基盤岩である中生代白亜紀の花崗岩か ら成る ${ }^{3)}$ (図-3)。被覆層は新第三紀の神戸層群, 第三
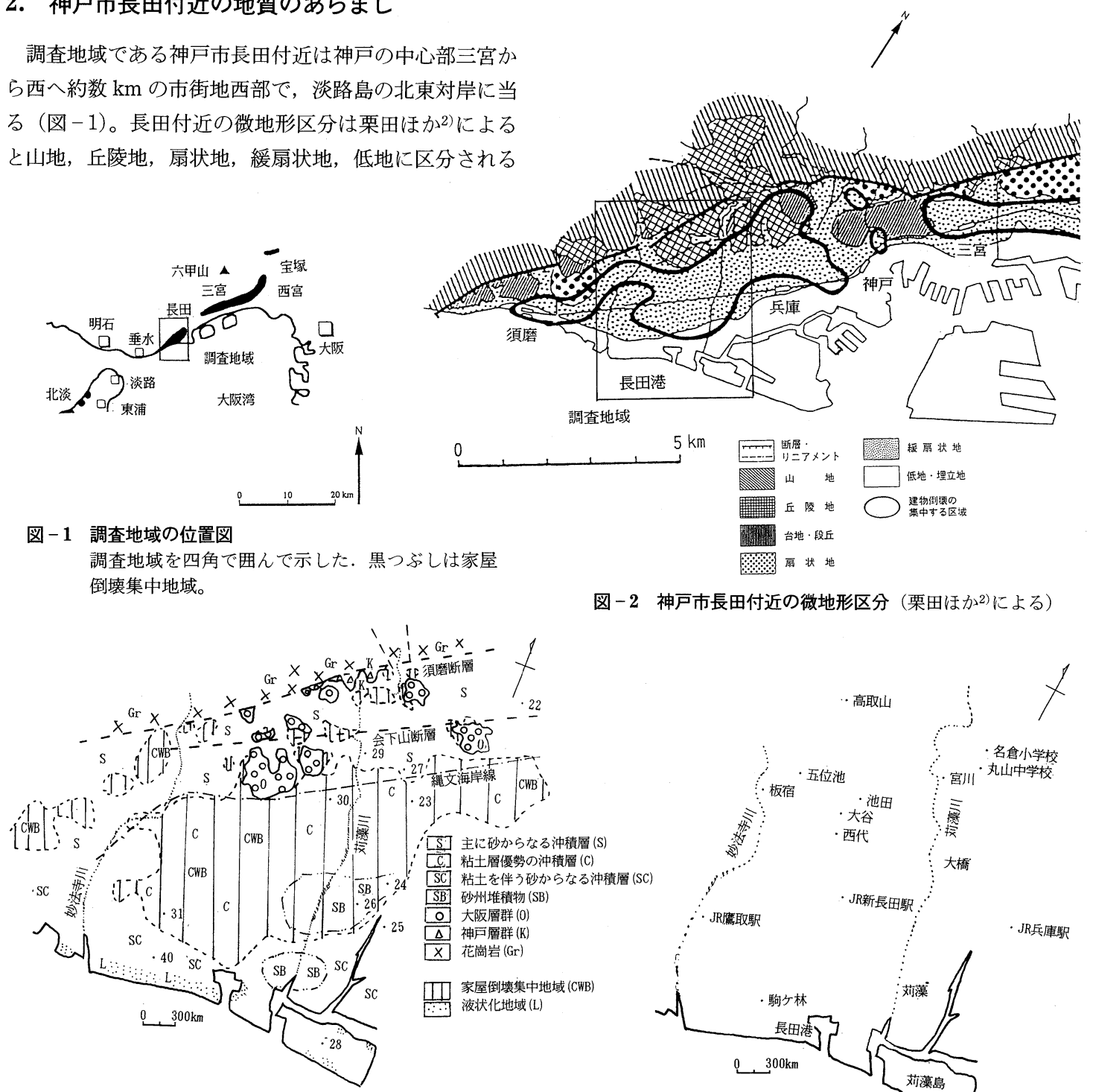

図-3 神戸市長田付近の地質と家屋倒壊集中地域との関係

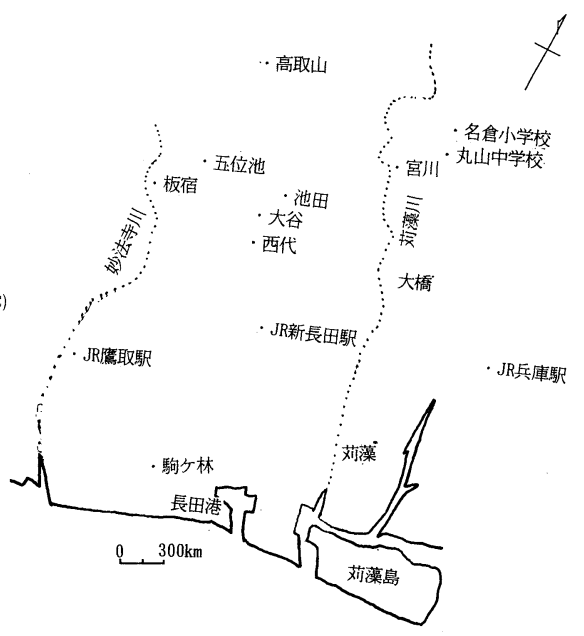

番号はボーリング位置を示す. 本報告で用いた地名も併せて示した。 
紀〜第四紀の大阪層群，それに沖積層である。

花崗岩は六甲花崗岩に属し, 中粒の黒雲母花崗岩から 成り山地に分布する。花崗岩は一般にしっかりした地盤 で硬岩と呼ばれ，良好な地盤と言えるが，風化状態や断 層沿いの破砕帯の存在や裂か状態などによって地盤状況 はかなり異なる。長田付近では花崗岩の風化作用は顕著 で, 特に, 須磨断層近くでは著しく風化作用が進んでい る。

神戸層群は本地域北東部の須磨断層南部付近の丘陵地 に小規模に分布する。岩質は多くは非凝圧質の砂岩やれ き岩から成るが，泥質岩む分布する。固結度が高いため 標高約 $40 \mathrm{~m}$ の高台や急崖をなすことが多い。北部の花
崗岩とは断層で接する。

大阪層群は山麓部に沿った丘陵地に産するが，山麓南 部の大谷や池田付近の丘陵地にも分布する（図-3)。 主に，砂れき層から成るが，海成粘土層も見られ，約 10度南に傾斜している。

沖積層を見ると, 縄文海岸線より北部の風化花崗岩を 起源に持つ主に砂から成る地域, 縄文海岸線より南部の 粘土を主とする粘土層優勢の地域，海岸部の粘土を伴う 砂から成る地域，そして速い潮流により形成された砂州 地域に区分される。岩見5の資料や神戸市のボーリング 資料6)加与（図一-4），縄文海岸線より北部は主に砂か ら，縄文海岸線より南部は主に粘土から成り，この区分

(22)

(23)

(24) (25) (26) (27) (28)

(29) (30)

(31) (40)
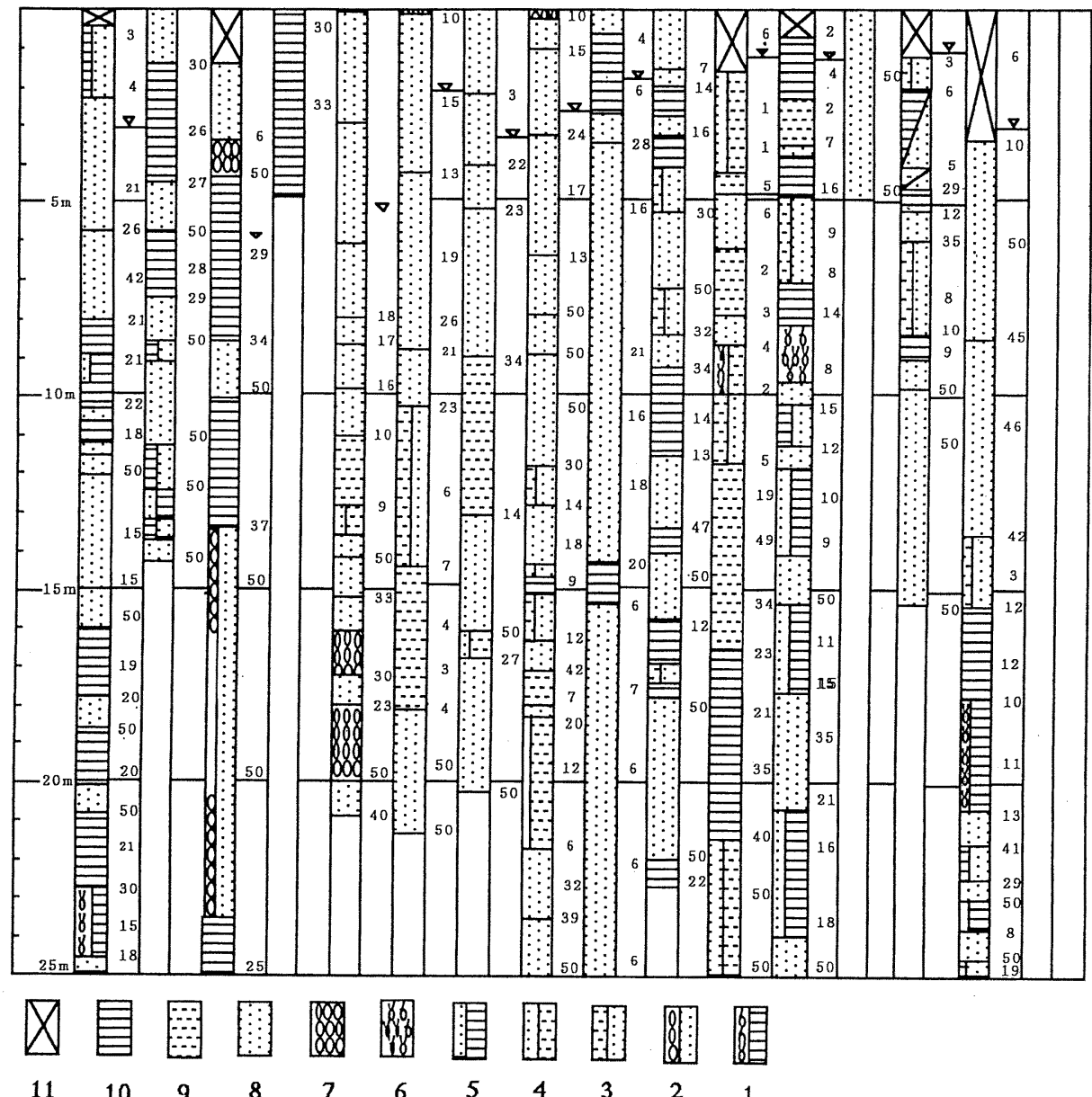

図 -4 神戸市長田付近のボーリング柱状図

1. 玉石混じり粘土，2. 玉石混じり砂，3. シルト混じり砂，4. 砂混じりシルト，5. 砂混じり粘土, 6. 砂混じり 玉石，7．玉石，8. 砂，シルト，9. 粘土，10. まさ，11. 資料欠損

ボーリング資料は岩見5) と神戸市企画局6)による，ボーリング位置は図-3 に番号で示した。 
を支持している。なお, JR 兵庫駅付近は砂を主体と し5), この付近にも砂州の存在が考えられる。これら長 田付近の沖積層の厚さは一部を除くと，一般に $10 \mathrm{~m}$ $20 \mathrm{~m}$ 前後である。また, 長田港付近には古い埋立地が 存在する。

断層は北部に須磨断層が分布する（図-3）。断層付 近では花崗岩は著しく圧砕され，北側には断層崖が発達 する。この地域では須磨断層の副断層が少し南に分布す るほか，共役関係にある北西～南東の断層も見られる。 また, 西部の板宿付近において須磨断層は沖積層分布地 域を通り，そこでは一部涌水が見られる。なお，須磨断 層の露頭において, 今回の地震による変位地形は見られ ない。会下山断層は須磨断層の南に分布する。主に沖積 層分布地域を通るため断層露頭は見られない。そこで， 断層の位置は藤田・笠間 3 にによった。断層沿いでは地震 による变位地形は見られない。約 6,000 年前の縄文海岸 線は比高約 4〜 $6 \mathrm{~m}$ の所にあり, 西代の北では小さい崖 をなし，連続して追跡できる。

\section{4. 地震被害と地質の関係}

長田付近は異なった地質が北から南に帯状に配列し， それに応じて地震被害が異なる。そこで，各地質区分毎 の地震被害の特徵を表- 1 に示し, その被害の状況を以 下に述べる。なお，家屋倒壊や地質の調査はすべて現地 で行い, 神戸市発行の 2,500 分の 1 の地形図に示した。

花崗岩地域 : 家屋の被害は少ない。須磨断層近傍の著 しく風化した地域で屋根瓦の損傷が見られるほか，壁の 剥離など住宅の一部損壊はあるが，全壊の建物は極めて

表-1 地質区分別に見た地震による家屋や地盤被害の特徴

\begin{tabular}{|c|c|c|}
\hline \multicolumn{2}{|r|}{ 地質区分 } & 家屋や地盤被害の特徵 \\
\hline \multicolumn{2}{|c|}{ 花崗岩地域 } & 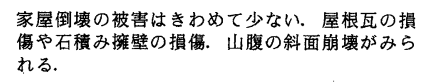 \\
\hline \multicolumn{2}{|c|}{ 神戸層群地域 } & $\begin{array}{l}\text { 家屋倒壊の被害は少ない. 石垣擁壁の損傷が生じ } \\
\text { て.いる. }\end{array}$ \\
\hline \multicolumn{2}{|c|}{ 大阪畨群地域 } & 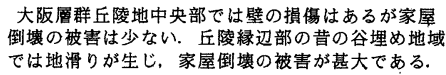 \\
\hline \multirow{2}{*}{$\begin{array}{l}\text { 沖 } \\
\text { 積 }\end{array}$} & 粘土層優勢地域 & $\begin{array}{l}\text { 家屋の70\%が倒噮するなど甚大な被害が生じた. ま } \\
\text { た. コンクリート建造物にも大きな被害が生じた. } \\
\text { 特に, 昔のため地埋土地での被害が顕著である. }\end{array}$ \\
\hline & $\begin{array}{l}\text { 主に砂からなる地 } \\
\text { 域 }\end{array}$ & $\begin{array}{l}\text { 家屋倒壊の被害は顕著であるが, 粘土層優勢地域 } \\
\text { より小さい. 昔のため池などの盛土した地域では大 } \\
\text { きな被害が生じた. }\end{array}$ \\
\hline \multirow{2}{*}{$\begin{array}{l}\text { 層 } \\
\text { 地 }\end{array}$} & $\begin{array}{l}\text { 粘土を伴う砂から } \\
\text { なる地域 }\end{array}$ & $\begin{array}{l}\text { 家屋の被害は多いが, 倒壤に到らず半壤のものが } \\
\text { 多い, }\end{array}$ \\
\hline & 砂州地域 & $\begin{array}{l}\text { 家屋の損傷は少なく, 倒壤は少なくなる. 液状化 } \\
\text { により護の倒壤がみられる. }\end{array}$ \\
\hline
\end{tabular}

少ない（図-5)。また, 石垣の縦亀裂など擁壁の損傷 が須磨断層近傍の急斜面地域に見られる。山地の斜面崩 壊は高取山山頂付近に見られるほか，小規模な自然斜面 の崩壊が断層崖上に見られる。なお，この地域は急傾斜 指定地が多いにもかかわらず格子枠安定加工などの人工 斜面はほとんど崩壊していない。

神戸層群地域 : 神戸層群地域は安定な軟岩地域で須磨 断層が分布するにもかかわらず，ほとんど大きな被害は 見られない。斜面崩壊も見られない。わずかに断層近傍 で石垣などの擁壁の縦亀裂が見られる。被害は名倉小学 校西の小丘陵地で見られるが，その地域は明治18年 （1885）測量の地形図によると，昔のため池の北端付近 に位置し（図-6のAの北部），ため池を埋め立てた土 地改変地域であり, 軟弱地盤にその原因を求めることが できる。

大阪層群地域 : 大阪層群地域はこれまで比較的安定地 盤とされてきた。大阪層群から成る丘陵地の中央部地域 では今回の地震で屋根瓦や壁の損傷などあるが，倒壊な ど大きな被害はない。しかし, 丘陵地の縁辺部では大き な被害が生じている。丸山中学校では斜面が崩壊し（写 真－1）, 直上の校舎が倒壊したほか, アスファルト道 路は滑落し, 崖下の家屋に大きな被害が生じた。また, 丸山中学校周辺も石垣擁壁のはらみだしや崩壊, 地盤の

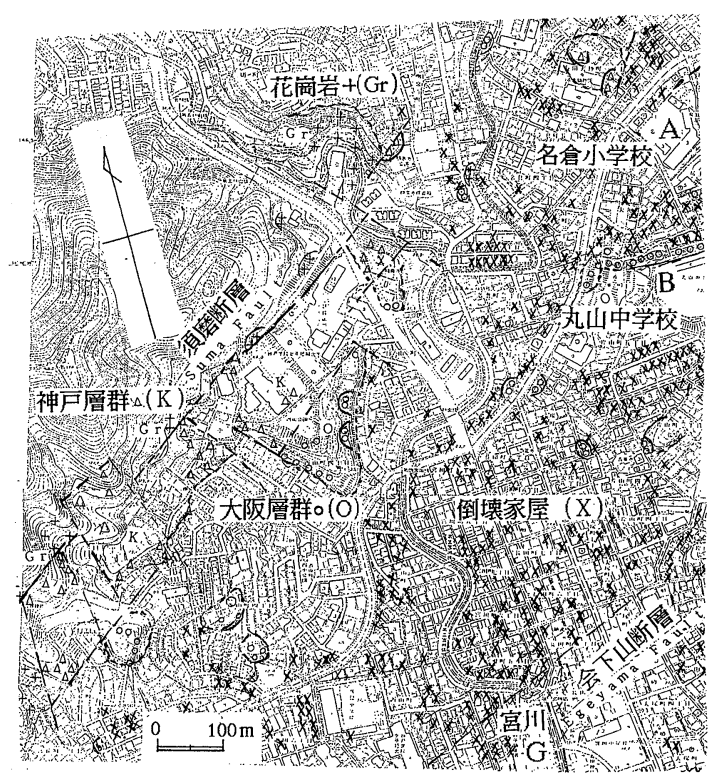

図-5 神戸市長田区名倉地区の倒壊家屋と地質・地形と の関係

$+(\mathbf{G r}):$ 花崗岩, $\Delta(\mathbf{K})$ : 神戸層群, $\bigcirc(\mathbf{O})$ : 大阪 層群, $\times(\mathbf{X})$ : 倒壊家屋。地形図は神戸市発行の 2,500 分の 1 , 長田, 夢野。 


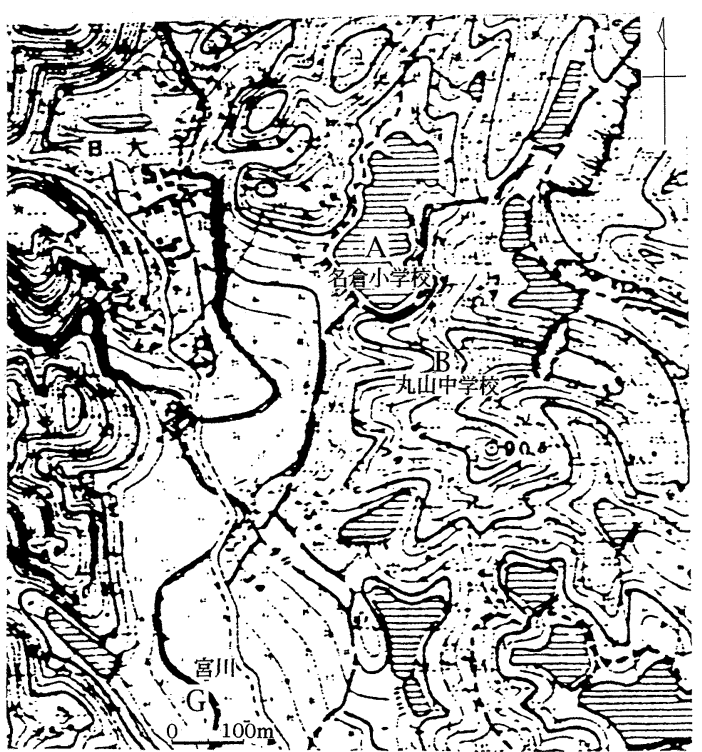

図-6 明治18年 (1885年) 測量の 20,000 分の 1 地形図, 兵庫, 神戸

$\mathbf{A}$ : 名倉小学校, $\mathbf{B}$ : 丸山中学校, $\mathbf{G}$ : 宮川

亀裂などほぼ全域壊隇的な被害が生じた（図 -5 のB）。 この地域は明治18年（1885年）測量の地形図によると 昔の谷地形でめり（図-6のB），崩壊斜面の堆積物か ら煉瓦などの人工物が見られ，大阪層群基盤の谷を埋め 立てた切り盛り境界が崩壊したと考えられる。昔の谷地 形の頭部では開口亀裂と陷没が見られ，谷の入口付近で はアスファルト道路の傾斜変換部での盛り上がりや石積 み擁壁のはらみだしなど圧縮による地盤変状が生じてお り，地滑りが生じた可能性を示唆している。また，名倉 小学校付近でも甚大な被害が生じた。これら倒壊家屋の 多くは昔のため池を埋土した地域に位置する（図-6の A)。そのため, 地盤が軟弱で, 地震動が増幅され, 多 くの被害が生じたと想像される。

大谷町の大阪層群地域でも被害が甚大である（図 -7 のC)。この地域も明治18年測量の地形図ではため池を 有する谷を埋めた人工地改変地域である（図-8の C)。家屋倒壊は昔の谷地形に沿って集中している。と くに，昔のため池を埋土した所では木造家屋の多くが倒 壊した（写真-2）。同じような例は池田の南や長田高 校の西の斜面でも見られ（図 -7 の D E ），やはり昔 の谷やため池を埋め立てた土地改変地域で被害が甚大で ある。これら谷埋め地域では斜面が集水溝として働くこ とが予想され，盛土の底部は水の集まりやすい部分であ ると考えられ，そこへ地震による強い振動が働いたため

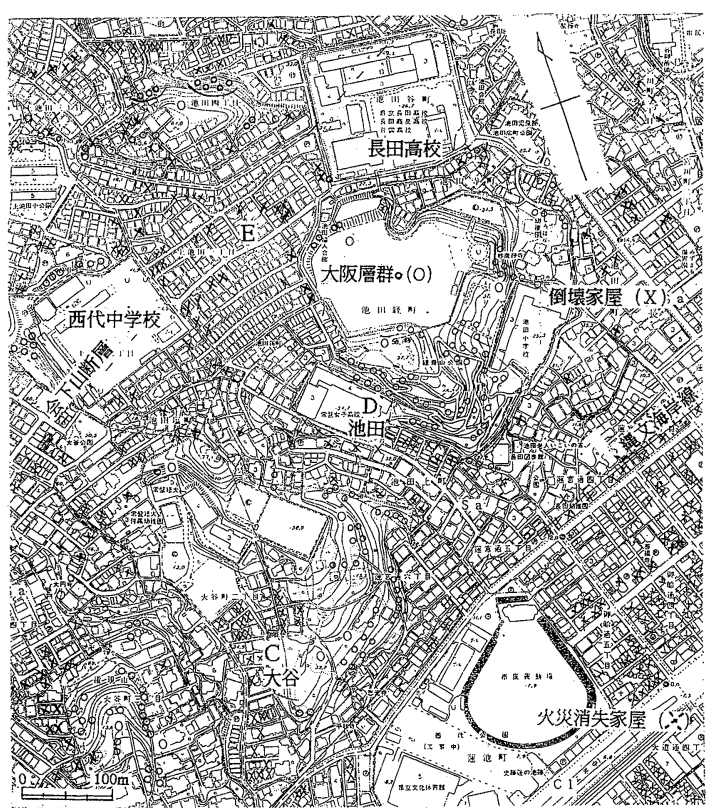

図-7 神戸市長田区池田, 大谷付近の倒壊家屋と地質・ 地形との関係

$\circ(\mathbf{O})$ : 大阪層群, $\times(\mathbf{X})$ : 倒壊家屋.

地形図は神戸市発行の 2,500 分の 1 , 長田

大きな被害となったと予想される。すなわち，盛土の部 分の荷重, 切土部斜面の高角化が, 地震の振動で不安定 となり，地盤被害を大きくした可能性が考えられる。昔 のため池を埋土した五位池付近では地盤は陥没し，鉄筋 コンクリート住宅は約 $30 \mathrm{~cm}$ 拔け上がり，噴砂が生じ ていることから，液状化したことを示している。このよ うに, 安定地盤とされた大阪層群地域です人工改変地形 地域では大きな被害が生じた。

沖積層地域 :この地域は縄文海岸線より北部の主に砂 から成る地域，縄文海岸線より南部の粘土層優勢地域打 よび海岸付近の粘土を伴う砂から成る地域と海岸部の砂 州地域に分けられ，被害の程度も異なるので個々に記載 する。

主に砂から成る地域：家屋倒壊の被害はあるが，粘土 層優勢地域に比べやや被害が少ない。この地域は主に砂 からなるため, 粘土層優勢地域より地盤がやや良いため 被害が少ないと考えられる。なお，この地域でも被害が 多い所が見られる。そこでは多くの木造家屋の基礎に亀 裂が生じ倒壊している。例えば西部の板宿地域は, 明治 18年測量の地形図によると昔の田やため池が分布し（図 -8 の) ） その後盛土した土地改変地域である。ま た，宮川地域も明治18年の地形図によると昔の田やた 

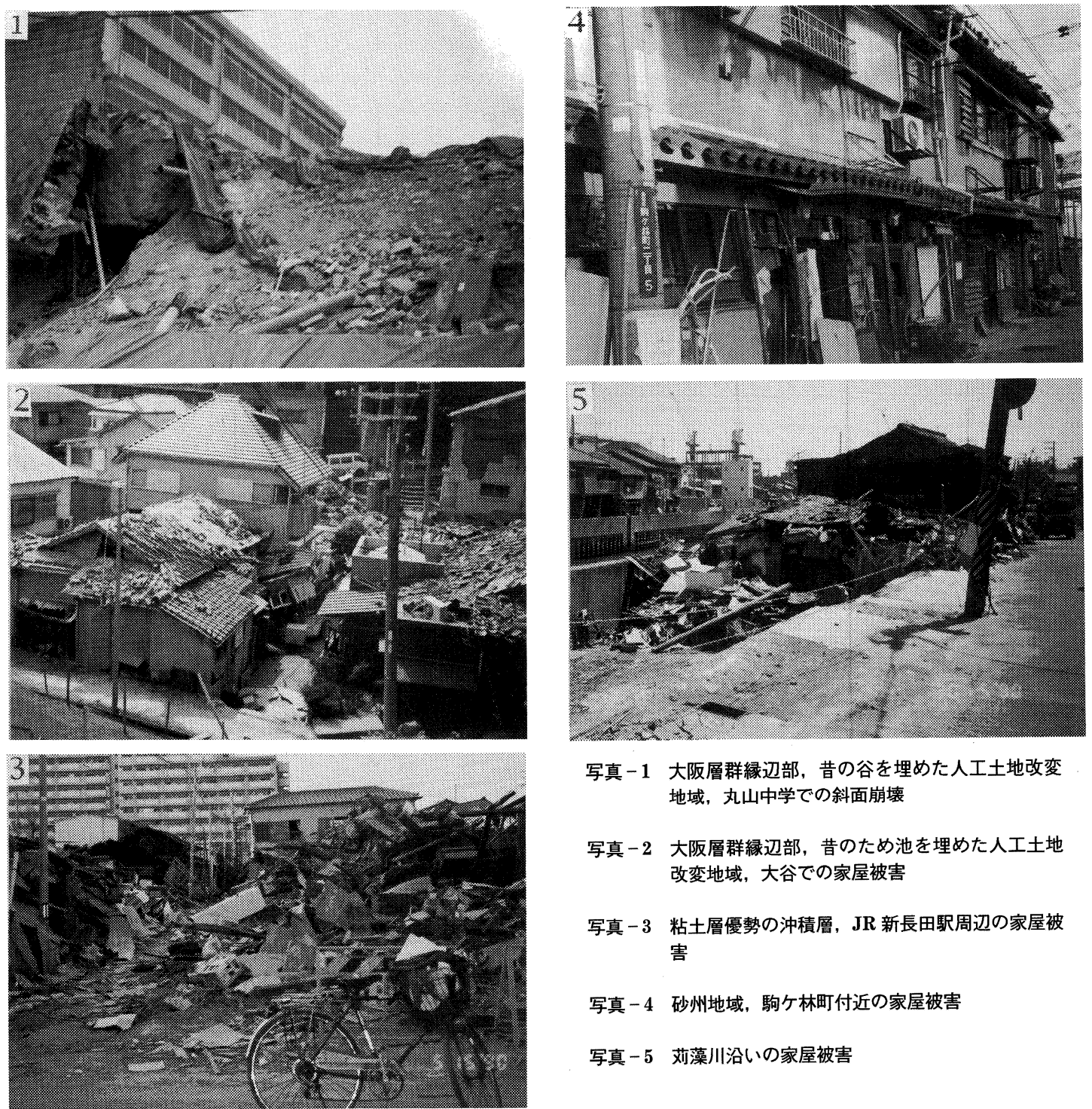

写真 -1 大阪層群縁辺部, 昔の谷を埋めた人工地改変 地域, 丸山中学での斜面崩壊

写真 - 2 大阪層群縁辺部, 昔のため池を埋めた人工土地 改変地域, 大谷での家屋被害

\section{写真 -3 粘土層優勢の沖積層, JR 新長田駅周辺の家屋被 害}

写真 -4 砂州地域, 駒ケ林町付近の家屋被害

写真 -5 苅藻川沿いの家屋被害

め池であり（図-6の G），土地改変地域である。この ように,これら人工改変地形地域は地盤が軟弱なため, 被害が大きくなったと考えられる。

粘土層優勢地域 : 地震で最も被害が大きかった地域で ある。この地域はかって沖合いに砂州が形成されたため ラグーン状態になり，そこに荻藻川から泥が運ばれ埋め 立てられ，この過程で水が滞留し，池ができるなど低湿 地帯となった場所と予想される。地盤が弱いため，ほと んどの木造家屋のほか鉄筋コンクリート建造物にも大き な被害が出た。とくに，JR 新長田駅付近では約 $70 \%$ の 木造住宅が倒壊する大きな被害を受けた（図-9)。こ
の地域は明治18年の地形図によると，昔の田およびた め池地域であった（図-8の H)。そこでは木造家屋の 一階部分が押しつぶされるなど大きな被害が生じた（写 真 -3$)$ 。苅藻川流域の大橋地域でも昔のため池があり (図-8の I), 被害が大きい。このように粘土層優勢の 地盤で, そのうえ, ため池を埋めた盛土地盤であるた め, 極端に地盤が弱く, 地震動が増幅され被害が大きく なったのであろう。低湿地を盛土した所に被害が多い傾 向は栗田ほか2)などによっても報告されている。この地 域のさらに南部の海岸近くになると, 地盤は粘土を伴う 砂から成る沖積層となり, 地盤がやや良くなるため被害 


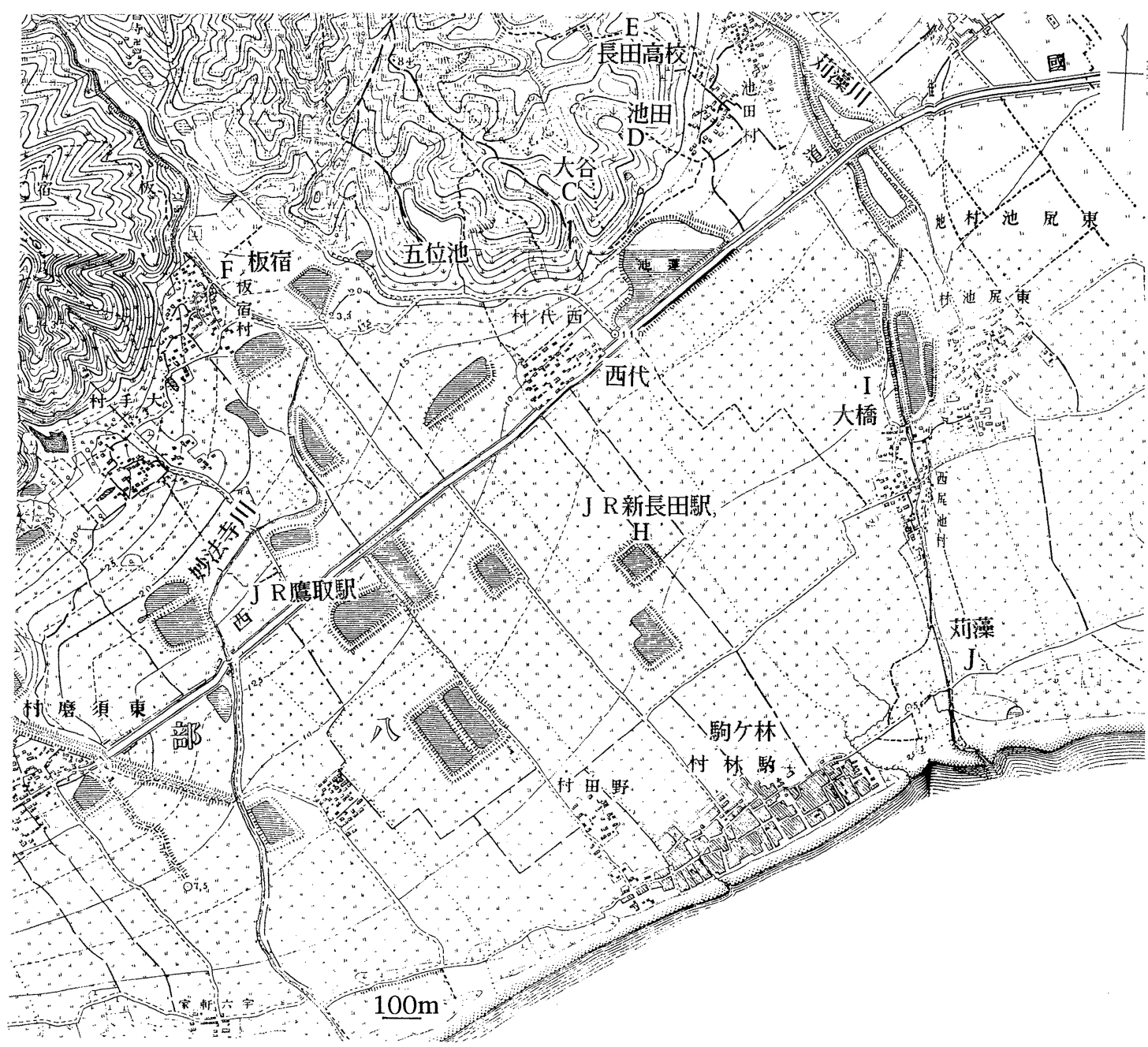

図-8 明治18年（1885年）測量の20,000分の 1 地形図, 神戸, 須磨村

$\mathbf{C}$ : 大谷, $\mathbf{D}:$ 池田, $\mathbf{E}:$ 長田高校, $\mathbf{F}:$ 板宿, $\mathbf{H}: \mathbf{J R}$ 新長田駅, $\mathbf{I}:$ 大橋, $\mathbf{J}:$ 苅藻

がやや少なくなる。

砂州地域 : 海岸付近の砂州地域では木造家屋の倒壊は 粘土層優勢地域より少なくなる（図-10）。この地域で は，家屋の損傷はあるが倒壊なで到らず（写真-4）, 粘土層優勢地域と被害の程度を異にしている。なお，苅 藻川の河川敷では多くの家屋倒壊が見られた（写真一 5)。

埋立地：長田港周辺は古い埋立地で，まさ土の押し出 しによる埋立地である。この付近は液状化が著しく, 石 油タンクが傾いている。この地域では側方流動が顕著 で, 護岸が海側へ張り出し, 護岸内側での陥没が著し w。

\section{5. よ め}

神戸市長田付近の兵庫県南部地震による家屋被害は地 質を反映している。

花崗岩や神戸層群地域は良好な地盤であるため, 須磨 断層が分布しているにもかかわらず大きな被害は見られ ない。

大阪層群地域は被害は少ないが，丘陵縁辺部の昔の谷 埋め地盤などの人工改变地形地域では大きな被害が生じ た。

沖積層地域を見ると, 縄文海岸線より南部の粘土層優 勢地域ではほとんどの木造住宅が倒壊するなど，甚大な 


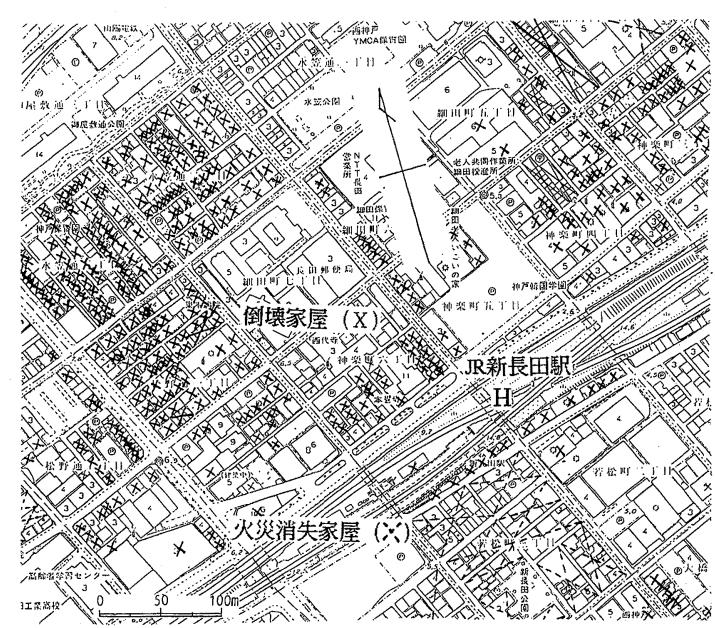

\section{図-9 神戸市長田区 JR 新長田駅付近の倒壊家屋と地形} との関係

×：倒壊家屋, 点線 : 火災消失家屋. $\mathbf{H}: \mathbf{J R}$ 新長

田駅.

地形図は神戸市発行の 2,500 分の 1 , 大橋

被害が生じた。この地域はかっての後背湿地と考えら れ，地盤が極めて弱いため，地震動が増幅され被害が大 きくなったと予想される。縄文海岸線より北部の砂を中 心とする地域では木造住宅は被害を受けたが，粘土層優 勢地域ほど著しくない。海岸沿いの砂州地域では大きな 被害は見られない。これは砂州地域が砂から成り，粘土 層優勢地域より地艋が良いためと考えられる。

\section{参 考 文 献}

1）田結庄良昭（1995）: 神戸長田地域の地震災害と地質, 地 盤との関係, シンポジウム「阪神・淡路大震災と地質環境」 論文集, pp. 149 - 154 .

2）栗田泰夫, 吉岡敏和, 水野清秀, 下川浩一, 宮地良典, 杉 山雄一, 寒川旭, 釜井俊孝, 磯部一洋, 奥村晃史, 佃栄

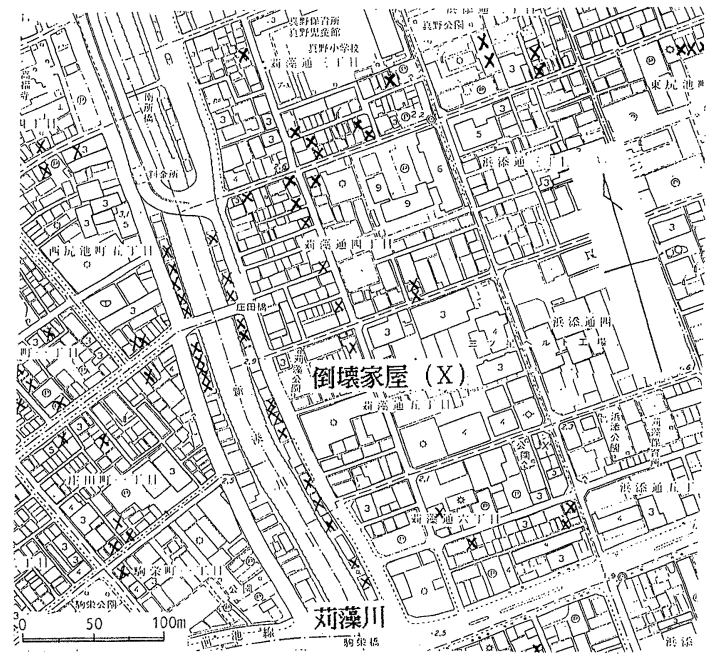

\section{図-10 神戸市長田区苅藻付近の倒壊家屋と地形との関係 $x:$ 倒壊家屋. \\ 地形図は神戸市発行の 2,500 分の 1 ，大橋}

吉, 吉田史郎, 鎌田浩毅, 松山紀香（1995）：1995年兵庫 県南部地震に伴う地震断層と地盤被害; 日本第四紀学会調 查速報, pp. $55-59$.

3）藤田和夫, 笠間太郎 (1971)：六甲山地とその周辺の地質, — 5 万分の 1 神戸市および隣接地域地質図, および説明書 一神戸市企画局, $58 \mathrm{p}$.

4）吉岡敏和, 地質調查所緊急調査グループ (1995)：1995年 兵庫県南部地震による阪神地域の被害分布と微地形区分, 日本地質学会 ·日本応用地質学会・関西地質調查業協会・ 断層資料研究センター・大阪市立大学「阪神大震災」学術 調查団共催, 「阪神大震災」緊急合同報告会資料集, pp. 88 -91 .

5）岩見義男（1980）：神戸の地盤特性，神戸市都市整備公社， $192 \mathrm{p}$.

6）神戸市企画局（1980）: 神戸の地盤, 神戸市企画局総合調 查課, $54 \mathrm{p}$.

(1995年 9 月 28 日受付, 1995年12月20日受理) 